
А. І. Гончарова ${ }^{1}$, аспірант
I. І. Моцний ${ }^{1}$, к.б.н., п.н.с.,
С. В. Чеботар ${ }^{1,2}$, д.б.н., п.н.с., член-кор.
${ }^{1}$ Селекційно-генетичний інститут - Національний центр насіннєзнавства та со- ртовивчення, Овідіопольська дорога, 3, Одеса, 65036, Україна,
${ }^{2}$ Одеський національний університет імені I. І. Мечникова, кафедра генетики i молекулярної біології, вул. Дворянська, 2, Одеса, 65082, Україна, е-mail: goncha- rovanastya@mail.ru

\section{ВПЛИВ АЛЕЛІВ ГЕНІВ КОРОТКОСТЕБЛОВОСТІ НА ДОВЖИНУ КОЛЕОПТИЛЯ ПШЕНИЦІ М'ЯКОЇ В УМОВАХ ОСМОТИЧНОГО СТРЕСУ}

\begin{abstract}
Досліджувався вплив алелів генів короткостебловості $(R h t)$ на проростання ліній-аналогів пшениці м'якої озимої в умовах осмотичного стресу. Встановлено, що наявність у генотипі алелів Rht веде до більшої редукції довжини колеоптиля у стресових умовах в порівнянні з умовами нормального водозабезпечення.
\end{abstract}

Ключові слова: осмотичний стрес; пшениця м'яка озима; гени короткостебловості; Rht; довжина колеоптиля.

Посуха є одним з основних абіотичних стресів, що впливає на різноманітні культурні рослини та їх врожайність у всьому світі. Це явище характеризується не просто дефіцитом вологи, а є складною комбінацією нестачі води, температурного стресу, суховію, засолення грунтів та інших абіотичних факторів. Збитки від посухи перевищують втрати від будь-якого іншого стресового фактору [2].

Регіональним екологічним центром для Центральної та Східної Європи були проаналізовані дослідження тенденцій зміни основних параметрів клімату Одеської, Миколаївської, Херсонської, Дніпропетровської та Запорізької областей [6]. Було встановлено, що сучасний клімат цих областей характеризується потеплінням. Останніми десятиріччями відбулися зміни в абсолютних максимумах та мінімумах температури повітря, які підвищилися на $1-4{ }^{\circ} \mathrm{C}$. Також більше стало днів із малоефективними зливами.

Як відмітив академік О. О. Іващенко [1], у зв'язку зі змінами клімату за останні десятиріччя в Україні відбувається зміщення кордонів природнокліматичних зон на 100-150 км на північ. Тому, на думку автора, умови вегетації рослин в традиційній підзоні Північного степу (Дніпропетровська, Кіровоградська області та інші) у останні роки фактично відповідають умовам підзони Південного Степу. На цей час у Південному Степу (Херсонська, Запорізька й інші області) проявляються ознаки опустелювання. Таким чином, 
головний ризик щодо стабільності урожайності в областях Півдня щодо продовольчої безпеки пов'язаний із посиленням посушливості.

Одним із критичних періодів реакції рослин на посуху є стадія проростання, оскільки відхилення від оптимальних умов уже в період проростання насіння негативно впливає на ріст і розвиток пшениці на всіх наступних етапах. Так, при пересиханні верхнього шару грунту після сівби можна одержати рідкі, так звані рвані сходи, що у подальшому зумовлює зменшення врожайності [5]. Довжина колеоптиля (ДК) опосередковано пов'язана з проявом посухостійкості пшениці м'якої озимої у фазі проростання [13]. ДК є одним з найважливіших показників для визначення посухостійкості пшениці, оскільки чим довший колеоптиль у рослини, тим глибшим можна робити посів, і тим ефективніше рослина буде використовувати вологу, що знаходиться у більш глибоких шарах грунту [12].

У багатьох роботах обговорюються положення щодо кращої пристосованості окремих генотипів пшениці м'якої озимої з генами короткостебловості $(R h t)$ до вирощування у певних еколого-кліматичних умовах, де такі генотипи дають високі та стабільні врожаї. Науковці із John Innes Centre [10] вказують на те, що селекція генотипів пшениці з геном короткостебловості Rht8c має високий потенціал в умовах дефіциту води. За даними Tang et al. [15], Rht8c представляється ідеальним геном-кандидатом для підвищення посухостійкості пшениці м'якої озимої, в той час як сорти і лінії, що містять гени Rht-Blb та $R h t-D l b$, не рекомендовано для вирощування в посушливих регіонах. Також Шаманіним і Лихенко [8] встановлено, що наявність у генотипі гену Rht2 (Rht$D 1 b)$ призводить до зниження врожаю ярої пшениці в посушливих умовах на $10,2 \%$ порівняно з контролем.

Існує неоднозначність щодо впливу генів $R h t$ на посухостійкість пшениці [5]. Так, в умовах дефіциту вологи, найбільшу посухостійкість за критерієм витрати води показали високорослі лінії, на другому місці за стійкістю до посухи були середньорослі форми, а найменшу посухостійкість зафіксовано у короткостеблових біотипів. У сортів короткостеблового типу, які мають добре розвинену кореневу систему, водний баланс більш сприятливий у період грунтової посухи, тому що у них на одиницю надземної маси припадає більше коренів, ніж у середньо- і високорослих форм. Цими ж авторами показано, що в умовах богари за кількістю зерен у головному колосі на фоні сортів Одеська 51, Херсонська 86 та Херсонська остиста виділявся сорт Одеська напівкарликова, в генотипі якого присутні гени Rht8c і Rht-Ble; а за масою 1000 зерен у кращій бік відрізнявся сорт Одеська 51 з одним геном $R h t 8 c$. Також цими дослідниками відмічено, що у короткостеблових сортів спостерігалася менша редукція колосків і квіток у період весняних посух (друга і третя декади травня). За даними В. М. Лєшина [3] сорти селекції СГІ-НЦНС, що містять у генотипі гени короткостебловості, характеризуються високою посухостійкістю. До таких сортів були віднесені сорти Одеська $51(R h t 8 c)$ і Альбатрос одеський (Rht8c i Rht-Dlb). 
Метою роботи було оцінити вплив алелів генів $R h t 8, R h t-B 1, R h t-D 1$ на ДК у ліній-аналогів, що різняться алелями генів короткостебловості, при проростанні в умовах осмотичного стресу.

\section{Матеріали та методи досліджень}

Матеріалом в дослідженні слугували короткостеблові аналоги сортів Кооператорка, Одеська 3, Одеська 51, Степняк 1, створені В. В. Хангільдіним та I. I. Моцним зі співавторами в СГІ - НЦНС, а також самі вихідні форми. За допомогою молекулярних маркерів було показано, що лінії-аналоги різняться алелями генів короткостебловості [7]. Враховуючи той факт, що сорт Карлик 1 було виведено шляхом хімічного мутагенезу із сорту Безоста 1 [4], а генетичний фон цих сортів приблизно однаковий, порівнювали пару сортів Безоста 1та Карлик 1 подібно лініям-аналогам. Алельна характеристика ліній-аналогів та рекурентних батьківських форм за генами короткостебловості представлена у таблиці 1.

Дослід проводили за методикою, запропонованою С. Ландьєвою із співавторами [12]. Осмотичний стрес моделювали за допомогою $15 \%$ розчину ПЕГ6000 (поліетиленгліколь). По 10 насінин кожної лінії-аналога пророщували у чашках Петрі на змоченому фільтрувальному папері в темряві за температури $+22{ }^{\circ} \mathrm{C}$. На контролі використовували дистильовану воду. Осмотичний стрес тривав 7 діб з початку пророщування. Через тиждень від початку експерименту у рослин вимірювали ДК. Дослід проводився у трьох повторностях. Статистичний аналіз результатів проводили у програмах Excel та Statistica 8.0. Достовірність різниці між ДК в умовах контролю та осмотичного стресу оцінювали за допомогою непараметричного U-критерія Манна-Уітні, який застосовується для порівняння даних малих вибірок.

\section{Результати досліджень та їх обговорення}

Шляхом пророщування короткостеблових ліній-аналогів пшениці м'якої озимої та їх рекурентних форм в умовах осмотичного стресу, змодельованого 15 \% ПЕГ-6000, встановлено вплив різних алелів генів Rht на ДК, яка опосередковано може впливати на посухостійкість рослин на стадії проростання.

Більш довгим колеоптилем характеризувалися рослини високорослих сортів Кооператорка, Одеська 3, Степняк 1 та Гостіанум 237 при вирощуванні на контролі (дистильована вода) і розчині 15 \% ПЕГ-6000 (табл. 1).

Різниця за ДК між рекурентними формами і короткостебловими лініямианалогами на контролі була меншою, ніж аналогічна різниця на 15 \% ПЕГ-6000 (табл. 2). Так, рослини сорту Кооператорка за ДК на контролі відрізнялись від його ліній-аналогів Кооператорка К-90 і Кооператорка К-70 на 12 і 37 \%, відповідно. В умовах осмотичного стресу ця різниця складала 26,9 та 58 \%, відповідно. Порівняння ДК між рослинами сорту Одеська 3 і лінії-аналога Одеська 
$3 К-75$ показало різницю у 27,4 \% - на контролі та 61,1 \% - на 15 \% ПЕГ-6000. Середня ДК рослин сорту Одеська 51 відрізнялась від такої у рослин лініїаналога Одеська 51 К-73 на 16,4 \% в умовах контролю і на 31 \% у досліді. Лінія Степняк 1 відрізнялась за ДК на контролі від ліній Степняк 3 та Степняк 2 К на 12 та 13,3\%, відповідно, а в умовах імітації осмотичного стресу на 26,9 та 25,1\% відповідно.

Таблиця 1

Характеристика рекурентних форм і ліній-аналогів за ознакою ДК

\begin{tabular}{|c|c|c|c|c|c|c|}
\hline \multirow{2}{*}{$\begin{array}{c}\text { Рекурентна форма/ } \\
\text { Лінія-аналог }\end{array}$} & \multicolumn{3}{|c|}{ Алелі генів $\boldsymbol{R h t}$} & \multirow[b]{2}{*}{$l_{0} \pm S_{\bar{x}}, \mathbf{M м}$} & \multirow{2}{*}{$l_{1} \pm S_{\bar{x}}, \mathbf{M M}$} & \multirow{2}{*}{$\begin{array}{c}\text { Достовірність } \\
\text { різниці }^{1} l_{0}-l_{1} \\
\text { мм }\end{array}$} \\
\hline & Rht8 & Rht-B1 & $R h t-\mathrm{D} 1$ & & & \\
\hline Кооператорка & $\mathrm{a}$ & $\mathrm{a}$ & a & $60,9 \pm 0,3$ & $53,1 \pm 4,8$ & $7,8^{* *}$ \\
\hline Кооператорка К-90 & $\mathrm{c}$ & $\mathrm{a}$ & $\mathrm{a}$ & $53,6 \pm 0,4$ & $38,5 \pm 4,4$ & $15,1^{* *}$ \\
\hline Кооператорка К-70 & $\mathrm{c}$ & e & $\mathrm{a}$ & $38,6 \pm 0,6$ & $22,3 \pm 3,9$ & $16,3 * *$ \\
\hline Одеська 3 & $\mathrm{a}$ & $\mathrm{a}$ & $\mathrm{a}$ & $63,1 \pm 0,1$ & $38,2 \pm 6,1$ & $24,9 * *$ \\
\hline Одеська 3 К-75 & $\mathrm{c}$ & $\mathrm{b}$ & $\mathrm{a}$ & $45,9 \pm 1,2$ & $14,0 \pm 3,6$ & $31,9 * *$ \\
\hline Одеська 51 & $\mathrm{c}$ & $\mathrm{a}$ & $\mathrm{a}$ & $57,3 \pm 2,1$ & $39,0 \pm 9,2$ & $18,3 * *$ \\
\hline Одеська 51 К-73 & $\mathrm{c}$ & e & a & $47,9 \pm 2,7$ & $26,9 \pm 5,6$ & $21,0 * *$ \\
\hline Степняк 1 & $\mathrm{a}$ & $\mathrm{a}$ & $\mathrm{a}$ & $55,6 \pm 3,1$ & $40,2 \pm 0,5$ & $15,4 * *$ \\
\hline Степняк 2 & $\mathrm{x}$ & $\mathrm{a}$ & $\mathrm{a}$ & $62,9 \pm 1,9$ & $34,0 \pm 8,5$ & $28,9 * *$ \\
\hline Степняк 3 & $\mathrm{c}$ & $\mathrm{a}$ & $\mathrm{a}$ & $62,9 \pm 4,3$ & $30,0 \pm 9,6$ & $32,9 * *$ \\
\hline Степняк 2К & $\mathrm{c}$ & $\mathrm{a}$ & $\mathrm{b}$ & $48,2 \pm 2,4$ & $30,1 \pm 5,8$ & $18,1 * *$ \\
\hline Одеська напівкарликова & $\mathrm{c}$ & $\mathrm{e}$ & $\mathrm{a}$ & $40,7 \pm 2,1$ & $30,8 \pm 5,7$ & $9,9^{*}$ \\
\hline Альбатрос одеський & $\mathrm{c}$ & a & $\mathrm{b}$ & $43,9 \pm 1,7$ & $30,1 \pm 7,2$ & $13,8 * *$ \\
\hline Гостіанум 237 & $\mathrm{a}$ & a & $\mathrm{a}$ & $61,4 \pm 1,7$ & $42,7 \pm 3,0$ & $18,7 * *$ \\
\hline Безоста 1 & $\mathrm{c}$ & $\mathrm{a}$ & $\mathrm{a}$ & $54,5+3,7$ & $31,0 \pm 3,6$ & $23,5 * *$ \\
\hline Карлик 1 & $\mathrm{c}$ & $\mathrm{b}$ & a & $33,5 \pm 2,8$ & $21,6+2,6$ & $11,9 * *$ \\
\hline
\end{tabular}

Примітка: $l_{0}$ - середнє значення ДК на контролі за три повтори; $l_{l}$ - середнє значення ДК на $15 \%$ ПЕГ-6000 за три повтори; $S$ - стандартна похибка; ${ }^{1}$ - достовірність різниці оцінювали за U-критерієм Манна-Уітні: * - $\mathrm{P}=0,05, * *-\mathrm{P}=0,01$. 
Ефекти алелів короткостебловості на ДК, встановлені при порівнянні з високорослими лініями-аналогами

\begin{tabular}{|c|c|c|c|c|}
\hline \multirow[t]{2}{*}{ Алелі $R h t$} & \multicolumn{2}{|c|}{$\begin{array}{c}\text { Зміна ДК під впливом алелів } \\
\text { генів Rht на контролі }\end{array}$} & \multicolumn{2}{|c|}{$\begin{array}{l}\text { Зміна ДК під впливом алелів генін } \\
\text { Rht в умовах імітації осмотичного } \\
\text { стресу }\end{array}$} \\
\hline & MM & $\%$ & MM & $\%$ \\
\hline Rht $8 c$ & $-7,3 * *$ & -12 & $-14,6 * *$ & $-26,9$ \\
\hline Rht8x & $+7,3 *$ & $+13,1$ & $-6,2$ & $-15,4$ \\
\hline$R h t-B 1 b$ & $-21,0 * *$ & $-38,5$ & $-9,4^{*}$ & $-30,3$ \\
\hline Rht-Ble & $-9,4 * * \mathrm{i}-15 * *$ & $-16,4$ i $-28,0$ & $\begin{array}{l}-12,1 * * \mathrm{i} \\
-16,2 * *\end{array}$ & $-31,0$ i $-42,1$ \\
\hline Rht-D1b & $-14,7 * *$ & $-23,4$ & $+0,1$ & $+0,3$ \\
\hline$R h t 8 c+R h t-B 1 b$ & $-17,2 * *$ & $-27,4$ & $-24,2 * *$ & $-61,1$ \\
\hline Rht $8 c+R h t-B 1 e$ & $-22,3 * *$ & $-37,0$ & $-30,8 * *$ & $-58,0$ \\
\hline$R h t 8 c+R h t-D 1 b$ & $-7,4 * *$ & $-13,3$ & $-10,1^{*}$ & $-25,1$ \\
\hline
\end{tabular}

Примітка. Достовірність різниці оцінювали за U-критерієм Манна-Уітні: * - $\mathrm{P}=0,05$, $* *-\mathrm{P}=0,01$.

В ході дослідження було встановлено, що наявність фрагмента ампліфікації 192 п. н. за мікросателітним локусом Xgwm261, який є діагностичним до алелю $R h t 8 c$, в генотипі пшениці м'якої озимої, асоціюється зі зменшенням ДК у стресових умовах на $12 \%$ порівняно із високорослими формами.

Досліджена лінія Степняк 2 - носій алеля 214 п. н. за локусом Xgwm261, який було асоційовано з Rht8x [7], має тенденцію до подовження колеоптиля відносно лінії Степняк 1 в умовах контролю. Натомість у стресових умовах ДК рослин лінії Степняк 2 була меншою, ніж ДК рослин рекурентної форми Степняк 1 на 15,4 \%, але різниця не була достовірною.

Ефект на ДК алеля Rht-Ble спостерігали у рослин ліній Кооператорка К-70 (при порівнянні з Кооператоркою К-90) та Одеської 51К-73 (при порівнянні 3 Одеською 51). В обох випадках відбувалось вкорочення колеоптиля, але у різній мірі. У першому випадку на контролі спостерігали зниження ДК на 28 \%, у другому - на 16,4 \%. В умовах стресу вкорочення колеоптиля було на рівні 42,1 \% у Кооператорки К-70 та 31 \% у Одеської 51К-73, порівняно з високорослими лініями. 
При порівнянні реакції на осмотичний стрес рослин сортів Безоста 1 (Rht8c) і Карлик $1(R h t 8 c+R h t-B 1 b)$ визначено вплив алеля $R h t-B 1 b$ на редукцію довжини колеоптиля. Так, в умовах контролю даний алель пов'язаний із зменшенням ДК на 38,5 \%, за умов осмотичного стресу різниця між ДК двох вищевказаних сортів складала $30,3 \%$.

При порівнянні ДК у генотипів Степняк $3(R h t 8 c)$ та Степняк $2 К(R h t 8 c+R h t$ $D 1 b)$ при пророщуванні зерна на $15 \%$ розчині ПЕГ-6000 не визначено достовірної різниці. Але на контролі різниця за ДК між цими генотипами становила $23,4 \%$.

Комбінації алелів генів короткостебловості в генотипах ліній-аналогів пшениці м'якої озимої достовірно впливали на зниження ДК рослин в умовах осмотичного стресу порівняно з контролем: $R h t 8 c+R h t-B 1 b-$ на $33,7 \%$, $R h t 8 c+R h t-B 1 e-$ на $21 \%$, Rht $8 c+R h t-D 1 b-$ на $11,8 \%$.

Результати дослідження, які показали вкорочення колеоптиля у лінійаналогів пшениці м'якої озимої з комбінацією генів $R h t 8 c+R h t-B 1 b$ в порівнянні з лініями-аналогами, що мають в генотипі ген $R h t 8 c$, в умовах контролю та осмотичного стресу, узгоджуються з даними інших дослідників $[9,12,13,14]$.

Згідно досліджень [9] присутність у генотипі пшениці м'якої озимої гену $R h t 8 c$ не призводить до зміни ДК в умовах нормального водозабезпечення. Tang $\mathrm{Na}$ із співавторами [15] показали, що ген Rht8c призводить до незначного вкорочення колеоптиля (6 \%) в умовах нормального водозабезпечення [15]. В нашій роботі ми спостерігали достовірне зменшення ДК у ліній-аналогів із геном $R h t 8 c$ на $12 \%$ в контрольних умовах порівняно з високорослими сортами. Вказані автори відзначили зменшення ДК в умовах нормального водозабезпечення у сортів із алелями $R h t-B 1 b, R h t-D 1 b$, комплексами алелів генів $R h t 8 c+R h t-B 1 b$ та $R h t 8 c+R h t-D 1 b$ на $25,4,31,3,28,4$ та $31,3 \%$ відповідно [15]. В нашій роботі ми отримали такі результати: алель $R h t-B 1 b$ в контрольних умовах призводив до вкорочення колеоптиля на $38,5 \%$, алель $R h t-D 1 b-$ на $23,4 \%$, комбінації алелів у генотипах ліній-аналогів $R h t 8 c+R h t-B 1 b$ та $R h t 8 c+R h t-D 1 b$ вплинули на зменшення ДК в умовах нормального водозабезпечення на 27,3 та 13,3\% відповідно.

Дослідження напівкарликових генотипів пшениці з різними генами Rht показало, що на ДК може впливати генетичний фон досліджуваних сортів і ліній [11]. Ми перевірили вплив генетичного фону на зміну ДК у ліній-аналогів в умовах осмотичного стресу (рис. 1). Так, на представленій діаграмі на осі ординат відображено різницю за ДК, яку визначено при порівнянні рослин, що вирощували в умовах контролю та осмотичного стресу, на осі абсцис наведено генетичний фон досліджуваних ліній. Доведено, що генетичні фони досліджуваних сортів впливають на різницю за ДК в контрольних та стресових умовах. Чим ближче точка на графіку знаходиться до «0» на осі ординат, тим менше даний генотип реагує на осмотичний стрес шляхом зменшення росту колеоптиля. Слід зазначити, що на генетичному фоні сорту Кооператорка лінії-аналоги 
характеризувалися невеликою різницею (7,8-16,4 мм) за ДК на контролі та в досліді, що свідчить - генетичний фон сорту Кооператорка сприяв кращому проростанню зернівок в умовах осмотичного стресу.

У рослин сорту Одеської 51 вкорочувався колеоптиль в умовах $15 \%$ ПЕГ6000 на 18,3 мм, а у рослин лінії-аналога Одеської 51К-73 - на 21 мм. Це вказує на дещо більшу чутливість генетичного фону Одеської 51 до осмотичного стресу, в порівнянні з генетичним фоном сорту Кооператорка.

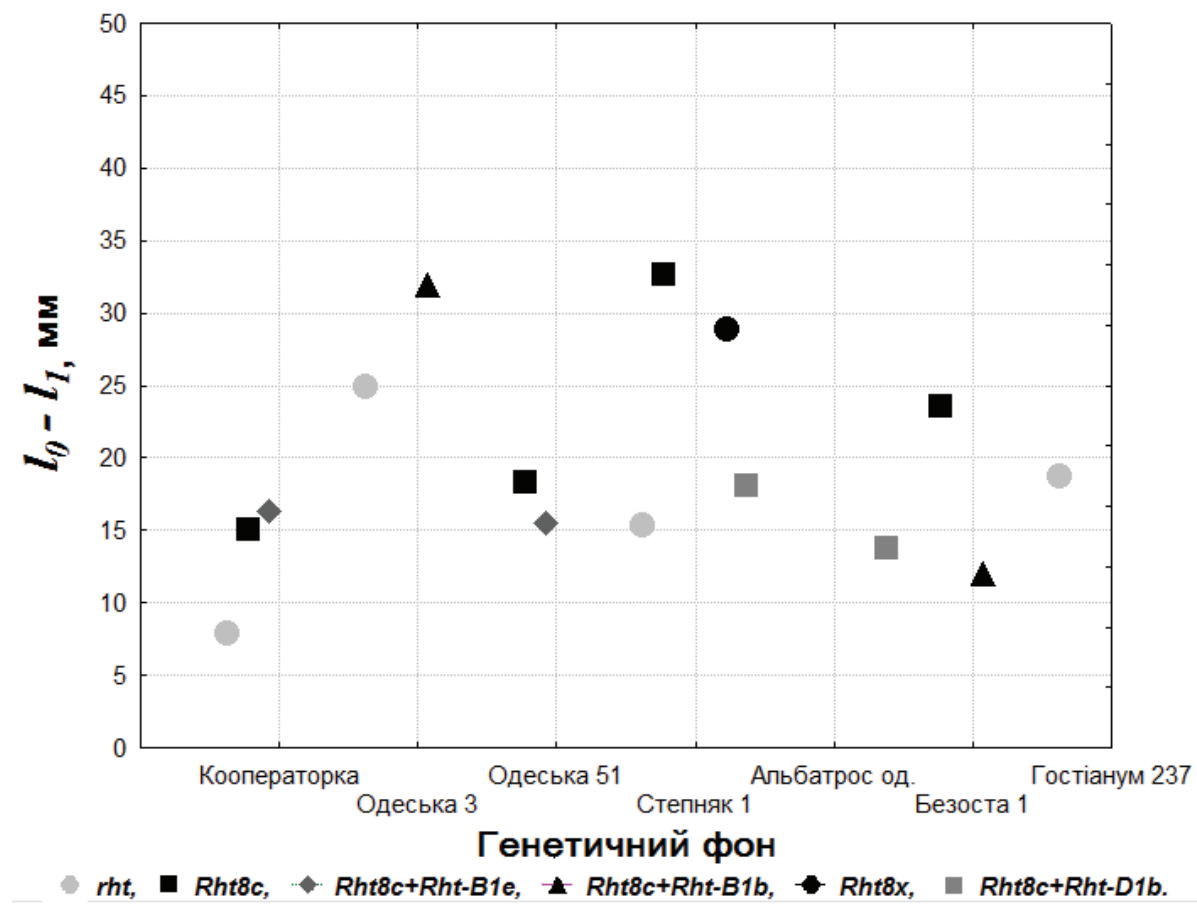

Рис. 1. Вплив осмотичного стресу на редукиію ДК ліній-аналогів пшениці м'якої озимої з різними генами короткостебловості в залежності від генетичного фону; $l_{0}$ - середнє значення ДК на контролі; $l_{l}$ - середнє значення ДК на 15\% ПЕГ-6000

Для ліній-аналогів Одеської 3 та Одеської 3К-75 була характерною різниця ДК в умовах контролю та 15 \% ПЕГ-6000 у 24,9 та 31,9 мм відповідно, що оцінювалось як негативний вплив генетичного фону Одеської 3 на здатність до проростання в умовах осмотичного стресу.

На генетичному фоні сорту Степняк лінії-аналоги дуже різнилися за реакцією на осмотичний стрес: для ліній Степняк 1 та Степняк 2 К виявлена невелика різниця за ДК - 15,4 і 18,1 мм, визначена при порівнянні рослин, що пророщували у контрольних та стресових умовах, відносно цієї різниці у ліній Степняк 2 та Степняк 3 різниця була майже у 2 рази більшою, тобто 28,9 і 32,9 мм. 


\section{Висновки}

В умовах осмотичного стресу збільшується ефект алелів генів короткостебловості на реакцію рослин на водний дефіцит. На довжину колеоптиля в умовах осмотичного стресу в порівнянні з високорослими формами достовірно впливають у різній мірі алелі генів $R h t 8 c$ (на 25,4 і 26,9 \% (на різних генофонах), Rht-Blb (на 30,3\%), Rht-Ble на 31 і 42,1\% (на різних генофонах), $R h t 8 c+R h t-B 1 e(58 \%), R h t 8 c+R h t-B 1 b(61,6 \%)$ та Rht8c+Rht-Dlb $(25,1 \%)$.

Довжина колеоптиля ліній-аналогів пшениці м'якої озимої, що різняться за алелями генів $R h t$, залежить від генетичного фону.

\section{Список використаної літератури}

1. Иващенко A. A. Изменения климата грозят Украине потерей более половины пахотных земель / А. А. Иващенко // Зеркало недели. - 2012. - http://news.zn.ua/SOCIETY/izmeneniya_klimata_grozyat_ ukraine poterey_bolee_polovini_pahotnyh_zemel-108287.html

2. Крупнов В. А. Генетическая сложность и контекст-специфичность признаков урожая пшеницы в засушливых условиях / В. А. Крупнов // Вавиловский журнал генетики и селекции - 2013. - Т. 17, № 3. C. 524-534.

3. Лешин В. Н. Системы засухоустойчивости и возможность их использования в селекции озимой мягкой пшеницы: дисс. ... кандидата биол. наук: 06.01.05 / Лешин Виктор Николаевич. - О., 1991. - 153 с.

4. Лыфенко $C$. Ф. Селекция интенсивных сортов озимой мягкой пшеницы полукарликового типа / С. Ф. Лыфенко, Н. И. Ериняк, В. П. Федченко, Р. П. Бунтовский // Сборник научных трудов ВСГИ. 1980. - C. 19-32.

5. Орлюк А. П. Адаптивний і продуктивний потенціал пшениці: [монографія] / А. П. Орлюк, К. В. Гончарова. - Херсон: Айлант, 2002. - 276 с.

6. Підвищення стійкості до зміни клімату сільськогосподарського сектору Півдня України // Регіональний екологічний центр для Центральної та Східної Європи. - Сентендре, Угорщина, 2015. - 70 с.

7. Чеботарь Г. А. Молекулярно-генетический анализ линий-аналогов мягкой пшеницы, различающихся по высоте растений / Г. А. Чеботарь, С. В. Чеботарь, И. И. Моцный, Е. И. Лобанова, Ю. М. Сиволап // Вісник Одеського національного університету. - 2009. - Т. 14, Вип. 8. - С. 61-71.

8. Шаманин В. П. Изогенный метод в селекции яровой пшеницы на засухоустойчивость / В. П. Шаманин, И. Е. Лихенко // Первое Всесоюзное совещание по использованию изогенных линий в селекционногенетических экспериментах, 27-29 марта 1990 г.: сборник статей. - Новосибирск, 1991. - С. 81-91.

9. Ellis M. H. The effect of different height reducing genes on the early growth of wheat / M. H. Ellis, G. J. Rebetzke, P. Chandler, D. Bonnett, W. Spielmeyer, R. A. Richards // Functional Plant biology - 2004. - Vol. 31 P. 583-589.

10. Gasperini D. Genetic and physiological analysis of $R h t 8$ in bread wheat: an alternative source of semi-dwarfism with a reduced sensitivity to brassinosteroids / D. Gasperini, A. Greenland, P. Hedden, R. Dreos, W. Harwood, S. Griffiths // Journal of Experimental Botany. - 2012. - http://jxb.oxfordjournals.org/open_access.html for further details.

11. Jamali K. D. Coleoptile length studies in semi-dwarf wheat (Triticum aestivum L.) with different dwarfing genes / K. D. Jamali, S. Arain // Proceedings of the $11^{\text {th }}$ International wheat genetics symposium, 24-29 August 2008. - Brisbane, QLD, Australia. - P. 221-223.

12. Landjeva $S$. Seedling growth under osmotic stress and agronomic traits in Bulgarian semi-dwarf wheat: comparison of genotypes with Rht8 and/or Rht-B1 genes / S. Landjeva, T. Karceva, V. Korzun, G. Ganeva // Crop \& Pasture Science - 2011. - Vol. 62 - P. 1017-1025.

13. Rebetzke G. J. Genotypic increases in coleoptile length improves stand establishment, vigour and grain yield of deep-sown wheat / G. J. Rebetzke, R. A. Richards, N. A. Fettell, M. Long, A. G. Condon, R. I. Forrester, T. L. Botwright // Field Crops Research - 2007. - Vol. 100 (1) - P. 10-23. 
14. Rebetzke G. J. Genetic improvement of early vigour in wheat/G. J. Rebetzke, R. Richards // Australian Journal of Agricultural Research - 1999. - Vol. 50 - P. 291-301.

15. Tang $N a$. The effects of dwarfing genes (Rht-B1b, Rht-D1b, and Rht8) with different sensitivity to GA $\mathrm{G}_{3}$ on the coleoptile length and plant height of wheat / Tang Na, Jiang Ying, He Bei-Ru, Hu Yin-gang // Agricultural Sciences in China - 2009. - Vol. 8(9) - P. 1028-1038.

Стаття надійшла до редакції 15.01.2016

\begin{abstract}
А. И. Гончарова ${ }^{1}$, И. И. Моцный ${ }^{1}$, С. В.Чеботарь ${ }^{1,2}$
${ }^{1}$ Селекционно-генетический институт - Национальный центр семеноводства и сортоизучения, Овидиопольская дорога, 3, Одесса, 65036, Украина

${ }^{2}$ Одесский национальный университет им. И.И. Мечникова, кафедра генетики и молекулярной биологии, ул. Дворянская, 2, Одесса, 65082, Украина

\section{ВЛИЯНИЕ АЛЛЕЛЕЙ ГЕНОВ КОРОТКОСТЕБЕЛЬНОСТИ НА ДЛИНУ КОЛЕОПТИЛЯ ПШЕНИЦЫ МЯГКОЙ В УСЛОВИЯХ ОСМОТИЧЕСКОГО СТРЕССА}

\begin{abstract}
Резюме
Одним из критических периодов реакции растений на засуху является стадия прорастания. Отклонения от оптимальных условий уже в период прорастания семян негативно влияют на рост и развитие пшеницы на всех последующих этапах. Длина колеоптиля косвенно связана с проявлением засухоустойчивости пшеницы мягкой озимой в фазе прорастания.

Целью нашей работы была оценка влияния аллелей генов Rht8, Rht-B1, Rht-D1 на длину колеоптиля у линий-аналогов озимой мягкой пшеницы, которые различаются аллелями генов короткостебельности, при прорастании в условиях осмотического стресса. Осмотический стресс моделировали с помощью $15 \%$ раствора ПЭГ-6000. Стрессовые условия длились 7 суток с момента прорастания зерен.

Генотипы без генов короткостебельности характеризовались более длинным колеоптилем по сравнению с короткостебельными формами на контроле и на растворе ПЭГ. Разница по длине колеоптиля между исходными высокорослыми формами и коростебельными линиями-аналогами на контроле была меньшей, чем в условиях осмотического стресса.

Было установлено, что в условиях осмотического стресса длина колеоптиля у короткостебельных линий-аналогов была меньше, чем у высокорослых форм. На нее влияли (понижали) в разной степени аллели генов $R h t 8 c$ (на 25,4 и $26,9 \%$ (на разных генофонах), Rht-B1b (на 30,3\%), Rht-Ble на 31 и 42,1 \% (на разных генофонах), Rht8c+Rht-Ble (58\%), Rht8c+Rht-B1b (61,6\%) и Rht8c+Rht-Dlb $(25,1 \%)$. Показано, что длина колеоптиля линий-аналогов пшеницы мягкой озимой, которые различаются по генам $R h t$, зависит от генетического фона.
\end{abstract}

Ключевые слова: осмотический стресс; пшеница мягкая озимая; гены короткостебельности; Rht; длина колеоптиля. 
A. I. Honcharova ${ }^{1}$, I. I. Motsny ${ }^{1}$, S. V. Chebotar ${ }^{1,2}$

${ }^{1}$ Plant Breeding and Genetics Institute - National Center of Seed and Cultivar Investigation, 3, Ovidiopolska Road, Odesa, 65036, Ukraine

${ }^{2}$ Odesa National Mechnykov University,

2, Dvoraynska str., Odesa, 65082, Ukraine

\title{
EFFECTS OF THE DWARFING GENE ALLELES ON COLEOPTILE LENGTH OF BREAD WHEAT UNDER OSMOTIC STRESS CONDITIONS
}

\begin{abstract}
One of the critical periods of plant response to drought is the germination stage. Deviations from the optimal conditions of growth in the period of germination negatively affect the development of wheat plants in the following stages of ontogenesis. Coleoptile length is indirectly involved into the development of drought resistance of bread wheat at the germination stage.

The aim of our study was to evaluate the effect of gene alleles Rht 8 , Rht-Bl, $R h t-D 1$ on the coleoptile length of the analogue lines, which differ in Rht alleles, during germination under osmotic stress. Osmotic stress was simulated by using a $15 \%$ PEG-6000 solution. Stressful conditions were applied for 7 days from the germination beginning.

Genotypes without Rht genes were characterized by longer coleoptile compared with dwarfing forms on the control and PEG solution. The difference of coleoptile length between the parental tall forms and lines-analogues was lower in the control than in the osmotic stress conditions.

It has been found that coleoptile length of analogue lines is shorter in comparison with tall forms under osmotic stress conditions and depends on alleles: Rht8c (25.4 and $26.9 \%$ (on different genetic backgrounds), Rht-B1b (30.3\%), Rht-Ble 31 and $42.1 \%$ (on different genetic backgrounds), Rht $8 c+$ Rht-Ble (58\%), Rht $8 c+R h t-B 1 b$ $(61.6 \%)$, and $R h t 8 c+R h t-D 1 b(25.1 \%)$. It was shown that coleoptile length also depends on the genetic background.
\end{abstract}

Key words: osmotic stress; bread wheat; dwarfing genes; Rht; coleoptile length

\section{References}

1. Ivashchenko AA (2012) "Climate changes threaten the loss more than half of of arable lands of Ukraine" ["Izmeneniya klimata grozyat Ukraine poterej bolee poloviny pahotnyh zemel"'], ZN, UA http://news.zn.ua/ SOCIETY/izmeneniya_klimata_grozyat_ukraine_poterey_bolee_polovini_pahotnyh_zemel-108287.html

2. Krupnov VA (2013) "Genetic complexity and context-specificity of symptoms of wheat crop in dry conditions" ["Geneticheskaya slozhnost' i kontekst-specifichnost' priznakov urozhaya pshenicy v zasushlivyh usloviyah"], Vavilov J of Genetics and Breeding, No 17, 3, pp 524-534.

3. Leshin VN (1991) Systems of drought resistance and the ability to use them in breeding winter wheat [Sistemy zasuhoustojchivosti i vozmozhnost' ih ispol'zovaniya v selekcii ozimoj myagkoj pshenicy] dis. ... kand. biol. nauk], Odessa, $153 \mathrm{p}$.

4. Lyfenko SF, Erinyak NI, Fedchenko VP, Buntovskij RP (1980) "The breeding of intensive semi-dwarf varieties of bread wheat" ["Selekciya intensivnyh sortov ozimoj myagkoj pshenicy polukarlikovogo tipa"], Collection of scientific works PBGI, pp 19-32.

5. Orlyuk AP, Honcharova KV (2002) Adaptive and productive potential of wheat [Adaptyvnyy i produktyvnyy potentsial pshenytsi], Kherson: Aylant, $276 \mathrm{p}$. 
6. Regional Environmental Center for Central and Eastern Europe (2015) Increasing of resistance to climate change of agricultural sector of the South Ukraine [Pidvyshchennya stiykosti do zminy klimatu sil's'kohospodars'koho sektoru Pivdnya Ukrayiny], Sentendre, Hungary, 70 p.

7. Chebotar' GA, Chebotar' SV, Mocnyj II, Lobanova EI, Sivolap YUM (2009) "Molecular-genetics analysis of lines-analogues of bread wheat with difference plants height" ["Molekulyarno-geneticheskij analiz linij-analogov myagkoj pshenicy, razlichayushchihsya po vysote rastenij"], Odessa National University Herald. Biology, No 14, 8, pp 61-71.

8. SHamanin VP, Lihenko IE (1991) "Isogenic method in selection of spring wheat on drought", First All-Union Conference on the use of isogenic lines in breeding and genetic experiments ["Izogennyj metod v selekcii yarovoj pshenicy na zasuhoustojchivost'”], Novosibirsk, pp 81-91.

9. Ellis MH, Rebetzke GJ, Chandler P, Bonnett D, Spielmeyer W, Richard RA (2004) "The effect of different height reducing genes on the early growth of wheat", Functional Plant biology, No 31, pp 583-589.

10. Gasperini D, Greenland A, Hedden P, Dreos R, Harwood W, Griffiths S (2012) "Genetic and physiological analysis of $R h t 8$ in bread wheat: an alternative source of semi-dwarfism with a reduced sensitivity to brassinosteroids", Journal of Experimental Botany, No 63, 12, pp 4419-4436.

11. Jamali KD, Arain S (2008) "Coleoptile length studies in semi-dwarf wheat (Triticum aestivum L.) with different dwarfing genes", Proceedings of the $11^{\text {th }}$ International wheat genetics symposium, Brisbane, QLD, Australia, pp 221-223.

12. Landjeva S, Karceva T, Korzun V, Ganeva G (2011) "Seedling growth under osmotic stress and agronomic traits in Bulgarian semi-dwarf wheat: comparison of genotypes with Rht8 and/or Rht-B1 genes", Crop \& Pasture Science, No 62, pp 1017-1025.

13. Rebetzke GJ, Richards RA, Fettell NA, Long M, Condon AG, Forrester RI, Botwright TL (2007) "Genotypic increases in coleoptile length improves stand establishment, vigour and grain yield of deep-sown wheat", Field Crops Research, No 100 (1), pp 10-23.

14. Rebetzke GJ, Richards R (1999) "Genetic improvement of early vigour in wheat”, Australian J of Agricultural Research, No 50, pp 291-301.

15. Tang Na, Jiang Ying, He Bei-Ru, Hu Yin-gang (2009) "The effects of dwarfing genes (Rht-B1b, Rht-D1b, and $R h t 8)$ with different sensitivity to $\mathrm{GA}_{3}$ on the coleoptile length and plant height of wheat", Agricultural Sciences in China, No 8 (9), pp 1028-1038. 